\title{
ANALISIS LAPORAN KEUANGAN BERDASARKAN LIKUIDITAS PADA PT. BANK PEMBANGUNAN DAERAH SUMATERA BARAT CABANG UTAMA
}

\author{
Wira Mardila, Afriyeni \\ Akademi Keuangan dan Perbankan Padang \\ Afriyeni.yen@gmail.com
}

\begin{abstract}
This study was conducted to determine the level of liquidity in the regional development banks (BPD) western Sumatra main branch in the period December 2013 - December 2015. the purpose of this study was to analyze the financial statement balance in regional development banks (BPD) western Sumatra. This research is a descriptive study using data from the financial statements. analysis using liquidity ratios used to assess the soundness of banks based Quick ratio $(Q R)$, banking ratio (BR), and Loan to Deposit Ratio (LDR). The Research shows that the level of bank liquidity seen from the Quick Ratio $(Q R)$ regional development banks (BPD) west Sumatra year period from December 2013 December 2015, including the year 2013 amounted to QR 27.82\%, 2014 amounted to $25.56 \%$ and 2015 amounted to $29.11 \%$ the results are included in the category of healthy. Banking Ratio (BR) in December 2013 by 93.85\%, and then in December 2014 amounted to $93.06 \%$ and in December 2015 amounted to $94.71 \%$. These results are included in the category of unhealthy because exceed the standard requirements of Bank Indonesia. Loan to Deposit Ratio (LDR) in December 2013 amounted to 83.16\%, 81.92\% by December 2014 and December 2015 amounted to $82.17 \%$. These results included into the category of healthy.
\end{abstract}

Keywords : Financial Statement, Liquidity Soundness

\section{LATAR BELAKANG}

Pada era globalisasi saat ini peranan bank sangat penting bagi masyarakat Indonesia, karena pada dasarnya bank bertujuan untuk menunjang pembangunan nasional dalam meningkatkan kesejahteraan masyarakat. Bank merupakan salah satu lembaga keuangan yang mempunyai peranan penting dalam perekonomian suatu negara. Bank dalam pasal 1 ayat(2) UU No.10

Tahun 1998 tentang perubahan UU No.7 Tahun 1992 tentang perbankan, pengertian Bank adalah badan usaha yang menghimpun dana dari masyarakat dalam bentuk simpanan dan menyalurkannya kepada masyarakat dalam bentuk kredit atau bentukbentuk lainnya dalam rangka meningkatkan taraf hidup rakyat banyak.

Berdasarkan Undang-Undang No.10 Tahun 1998 tentang perbankan, menurut jenisnya bank terdiri dari Bank Umum dan Bank Perkreditan Rakyat (BPR). Bank umum adalah bank yang melaksanakan kegiatan usaha secara konvensional dan/atau berdasarkan prinsip syariah yang dalam kegiatannya memberikan jasa dalam lalu lintas pembayaran. Sifat jasa yang diberikan adalah umum, dalam arti dapat memberikan seluruh jasa perbankan yang ada.

Bank Indonesia mendorong penguatan daya saing dan kelembagaan Bank Pembangunan Daerah (BPD). Bank semacam ini dianggap mampu memperkuat 
perekonomian daerah dan berfungsi sebagai agen pembangunan setempat. Agar dapat melaksanakan tugas pokok dan mempertahankan kelangsungan bank, kepercayaan masyarakat sangat penting. Untuk memperoleh gambaran tentang perkembangan finansial suatu bank, perlu mengadakan analisa atau interpretasi terhadap data finansial dari bank yang bersangkutan. Dimana data finansial itu tercermin di dalam Laporan Keuangan.

Laporan Keuangan merupakan data-data keuangan yang sifatnya kuantitatif. Menurut Harahap (2009:105) laporan keuangan menggambarkan kondisi keuangan dan hasil usaha suatu perusahaan pada saat tertentu atau jangka waktu tertentu. Adapun jenis laporan keuangan yang lazim dikenal adalah neraca, laporan laba rugi atau hasil usaha, laporan perubahan ekuitas, laporan arus kas, dan laporan posisi keuangan. Untuk memperoleh perkembangan atau kinerja kegiatan usaha suatu bank perlu diadakan suatu interpretasi atau analisa terhadap finansial bank yang bersangkutan.

Dalam menganalisa dan menilai posisi keuangan untuk mengetahui seberapa jauh kemampuan bank dalam memenuhi kewajibannya, baik kewajiban kepada pihak intern maupun ekstern serta mengetahui potensi dan kemajuan suatu bank, maka faktor utama yang ditentukan salah satunya yaitu aspek likuiditas.

Pengertian likuiditas menurut Weston dalam Kasmir (2008 : 129) adalah rasio yang menggambarkan kemampuan terhadap utang jangka pendek. Artinya, apabila perusahaan ditagih maka perusahaan tersebut mampu memenuhi utang (membayarnya) terutama utang yang sudah jatuh tempo.

Menurut pengertian ini suatu bank dikatakan Likuid apabila :

a. Bank tersebut memiliki cash asset sebesar kebutuhan yang akan digunakan untuk memenuhi likuiditasnya.

b. Bank tersebut memiliki cash asset yang lebih kecil dari yang tersebut diatas, tetapi yang bersangkutan juga memiliki asset lainnya (khususnya surat- surat berharga) yang dapat dicairkan sewaktu-waktu tanpa mengalami penurunan nilai pasarnya.

c. Bank tersebut mempunyai kemampuan untuk menciptakan cash asset baru melalui berbagai bentuk hutang.

Menurut Kasmir (2008 : 134) Rasio Likuiditas dapat diukur dengan beberapa rasio-rasio keuangan yaitu : current ratio $(C R)$, quick ratio $(Q R)$ dan loan to deposit ratio $(L D R)$. Pada $C R$ menunjukan kemampuan bank untuk melunasi kewajiban- kewajiban yang segera yang harus dibayar, $Q R$ Merupakan rasio yang digunakan untuk mengukur kemampuan bank dalam memenuhi kewajibannya terhadap para deposan (pemilik simpanan giro, tabungan dan deposito) dengan harta yang paling likuid yang dimiliki oleh bank, dan LDR merupakan rasio yang digunakan untuk mengukur komposisi jumlah kredit yang diberikan dibandingkan dengan jumlah dana masyarakat dan modal sendiri yang digunakan.

Kita sering kali mendengar atau bahkan melihat ada bank yang tidak mampu atau tidak sanggup untuk membayar seluruh atau sebagian utang (kewajibannya) yang sudah jatuh tempo pada saat ditagih, atau terkadang bank juga sering tidak memiliki dana untuk membayar kewajibannya tepat waktu, hal ini terjadi karena bank tidak memiliki dana yang cukup untuk menutupi utang yang jatuh tempo tersebut.

Kasus seperti ini akan sangat mengganggu hubungan baik antara bank dengan para kreditor, dalam jangka panjang kasus ini akan berdampak pula kepada para nasabah (deposan). Artinya, pada akhirnya bank akan mengalami krisis kepercayaan dari berbagai pihak yang selama ini membantu kelancaran usahanya. Padahal kita tahu bahwa kepercayaan dari berbagai pihak terhadap bank merupakan modal utama bank dalam mencapai target yang telah ditetapkan.

PT. BPD Sumbar merupakan salah satu bank umum yang terletak di Kota 
Padang, yang berperan dalam memberikan kontribusi aktif dalam bidang pembangunan, khususnya dibidang kredit. Dalam pembiayaan kredit tersebut tentunya bank memerlukan dana yang tidak sedikit disamping harus memenuhi kewajiban-kewajiban operasional lainnya. Oleh karena itu, PT. BPD Sumbar harus mampu menghimpun dana dan menggunakan dana tersebut secara efektif dan efisien sehingga tidak terjadi kegagalan dalam memenuhi kewajiban ataupun mengalami (idle money) sehingga likuiditas bank bisa dijaga.

Sebagai Perusahaan Perbankan, PT. BPD Sumbar harus memperhatikan tingkat likuiditas dalam mengelola semua asset yang dimiliki agar terwujud likuiditas yang lancar di masa yang akan datang. Berikut ini adalah hasil perkembangan analisis Rasio Likuiditas PT. BPD Sumbar untuk periode tahunan, Desember 2013- Desember 2015.

\section{Tabel 1}

Perkembangan Rasio Likuiditas PT. BPD Sumbar Periode Desember 2013- Desember 2015

\begin{tabular}{|l|c|c|c}
\hline Keterangan & Des & Des & $\begin{array}{r}\text { Des } \\
\end{array}$ \\
\hline QR & 2013 & $\mathbf{2 0 1 4}$ & $\mathbf{2 0 1 5}$ \\
\hline BR & & 25,56 & $29,11 \%$ \\
& $93,85 \%$ & 93,06 & $94,71 \%$ \\
\hline LDR & & $\%$ & \\
& $83,16 \%$ & 81,92 & $82,17 \%$ \\
\hline
\end{tabular}

Sumber: PT. BPD Sumbar, data diolah.

PT.BPD Sumbar dalam hal ini neraca perusahaannya dalam posisi likuiditas mengalami fluktuasi, ini bisa dilihat dari tiga indikator rasio likuiditas yaitu Quick Ratio, Banking Ratio, dan Loan to Deposit Ratio. QR berdasarkan standar Bank Indonesia (BI) 15\%-20\% tergolong sehat. $Q R$ pada Desember 2014 $(25,56 \%)$ tergolong sehat, dan pada Desember $2015 Q R$ naik sebesar

$3,55 \%$, sehingga menjadi $(29,11 \%)$, tergolong sehat. $B R$ menurut standar Bank Indonesia 75\%-85\% tergolong sehat. $B R$ pada Desember $2014(93,06 \%)$ tergolong tidak sehat, dan pada Desember 2015 naik sebesar

$1,65 \%$, sehingga menjadi $(94,71 \%)$, tergolong tidak sehat. Untuk $L D R$ menurut standar Bank Indonesia

$78 \%-92 \%$ tergolong sehat. Sebagaimana terlihat pada Desember

2014 LDR $(81,92 \%)$ tergolong sehat, dan pada Desember 2015 naik sebesar $0,25 \%$ sehingga menjadi $(82,17 \%)$, tergolong sehat.

Untuk menentukan kebijakan- kebijakan yang diambil dalam mempertahankan posisi likuiditas yang sehat dengan tetap memenuhi kewajiban penyaluran dana dalam rangka menjaga kelangsungan operasional perusahaan, maka sangatlah penting untuk menilai tingkat likuiditas bank tersebut. Menilai tingkat likuiditas PT. BPD Sumbar dengan menggunakan beberapa rasio likuiditas yang lazim digunakan dalam suatu bank.

Berdasarkan latar belakang diatas penulis tertarik untuk melakukan penelitian pada PT. BPD Sumbar dengan Judul "Analisis Laporan Keuangan Berdasarkan Tingkat Likuiditas Pada PT. Bank Pembangunan Daerah Sumatera Barat Cabang Utama“.

Berdasarkan uraian latar belakang tersebut, maka yang dibahas dalam tugas akhir ini yaitu tentang bagaimana tingkat likuiditas pada PT. BPD Sumbar. 
penting di dalam perekonomian suatu negara sebagai lembaga perantara keuangan. Menurut Undang-Undang No.10Tahun 1998 tentang perubahan Undang-undang No.7 Tahun 1992 tentang perbankan, bank adalah badan usaha yang menghimpun dana dari masyarakat dalam bentuk simpanan dan menyalurkannya kepada masyarakat dalam bentuk kredit dan atau bentuk-bentuk lain dalam rangka meningkatkan taraf hidup rakyat banyak. Sedangkan menurut Kasmir (2012:24) bank adalah suatu jenis lembaga keuangan yang melaksanakan berbagai macam jasa, seperti memberikan pinjaman, mengedarkan mata uang, pengawasan terhadap mata uang, bertindak sebagai tempat penyimpanan benda-benda berharga, membiayai perusahaan-perusahaan dan lainlain. Pengertian lain tentang bank menurut Suyatno (1993:10) adalah usaha yang bertujuan untuk memuaskan kebutuhan kredit, baik dengan alat-alat pembayaran sendiri atau dengan uang yang diperoleh dari orang lain maupun dengan jalan memperedarkan alat-alat penukaran baru berupa uang giral.

Menurut Undang-Undang NO. 10 Tahun 1998 tentang perbankan, bank terdiri atas dua jenis, yaitu :

\section{a. Bank Umum}

Pengertian Bank Umum menurut Peraturan Bank Indonesia No.9/7/PBI/2007 adalah bank yang melaksanakan kegiatan usaha secara konvensional dan atau berdasarkan prinsi syariah yang dalam kegiatannya memberikan jasa dalam lalu lintas pembayaran. Bank umum sering disebut bank komersil (Commercial Bank).

b. Bank Perkreditan Rakyat

Bank Perkreditan Rakyat (BPR) adalah bank yang melaksanakan kegiatan usaha secara konvensional atau berdasarkan prinsip syariah yang dalam kegiatannya tidak memberikan jasa dalam lalu lintas pembayaran.

\section{Pengertian Laporan Keuangan}

Laporan keuangan merupakan suatu data yang memberikan informasi tentang keadaan keuangan suatu perusahaan pada tanggal tertentu dan periode tertentu yang disajikan dalam bentuk laporan keuangan yang mengacu pada Standar Akuntansi Keuangan (SAK) yang berlaku. Berdasarkan defenisi yang tersebut diatas, dapat tarik kesimpulan bahwa tujuan dari laporan keuangan tersebut ialah :

\section{Jenis-jenis Laporan Keuangan}

1) Neraca.

Neraca merupakan laporan keuangan yang menunjukkan posisi keuangan bank pada tanggal tertentu. Posisi keuangan yang dimaksud adalah aktiva dan pasiva suatu bank.

2) Laporan Komitmet dan Kontijensi.

Laporan komitmen dan kontijensi merupakan suatu ikatan atau kontrak yang berupa janji yang tidak dapat dibatalkan secara sepihak (irrevocable) dan harus dilaksanakan sesuai dengan kesepakatan bersama.

3) Laporan Laba rugi

Laporan laba rugi merupakan laporan keuangan yang menggambarkan semua hasil dan kewajiban-kewajiban operasional suatu bank dalam periode tertentu.

4) Laporan Arus Kas

Laporan arus kas merupakan laporan yang menunjukkan semua aspek yang berkaitan dengan kegiatan bank, baik yang berpengaruh langsung maupun tidak langsung terhadap kas. Laporan arus kas harus disusun berdasarkan konsep kas selama periode laporan.

5) Catatan Atas Laporan Keuangan.

Catatan atas laporan keuangan merupakan laporan yang berisi catatan tersendiri mengenai posisi devisa netto menurut jenis mata uang dan aktivitas lainnya. 
6) Laporan Keuangan Gabungan dan Konsolidasi.

Laporan keuangan gabungan dan konsolidasi merupakan laporan dari cabangcabang bank yang bersangkutan, baik yang ada di dalam maupun di luar negeri. Sedangkan laporan keuangan konsolidasi merupakan lapran keuangan bank yang bersangkutan dengan anak perusahaan.

\section{Pengertian Likuiditas}

Likuiditas adalah kemampuan bank dalam memenuhi kewajiban (utang) jangka pendek. Artinya apabila bank ditagih, bank akan mampu untuk memenuhi utang tersebut terutama utang yang sudah jatuh tempo. Dengan kata lain kemampuan bank dalam memenuhi kewajiban yang sudah jatuh tempo, baik kewajiban kepada pihak luar bank (likuiditas badan usaha) maupun di dalam bank (likuiditas bank). yang bersangkutan juga memiliki asset lainnya (khususnya suratsurat berharga) yang dapat dicairkan sewaktu-waktu tanpa mengalami penurunan nilai pasarnya.

Dalam terminologi yang hampir sama, dapat disebutkan bahwa "likuiditas adalah kemampuan bank untuk menyediakan saldo kas dan saldo harta likuid yang lain untuk memenuhi kewajiban- kewajiban khususnya untuk :

1. Menutup jumlah reserve required.

2. Membentuk secondary reserve

3. Membayar cek, giro berbunga, tabungan dan deposito berjangka milik nasabah yang diuangkan kembali.

4. Menyediakan dana kredit yang diminta calan debitur sehat, sebagai bukti mereka tidak mentimpang dari kegiatan utama bank yaitu penyaluran dana (pemberian kredit).

5. Menutup berbagai macam kewajiban segara lainnya.

6. Menutup biaya operasinal perusahaan.

\section{Jenis dan Sumber Alat Likuiditas}

Berdasarkan pengertian ini bank di katakan likuid apabila :

a) Bank tersebut memiliki cash assets sebesar kebutuhan yang akan digunakan untuk memenuhi likuiditasnya.

b) Bank tersebut memiliki cash assets yang lebih kecil dari yang tersebut diatas, tetapi

Menurut terminologi yang berlaku umum dalam dunia perbankan, dapat disebutkan bahwa jenis-jenis alat likuid yang dimiliki oleh bank adalah :

1. Kas atau uang tunai (kertas atau logam) yang tersimpan

dalam brankas ( khasanah)

bank tersebut.

2. Saldo dana milik bank tersebut, yang terdapat pada Bank Sentral (Saldo Giro BI).

3. Tagihan atau deposito pada bank lain, termasuk bank koresponden.

4. Cek yang diterima, tetapi masih dalam proses penguangan pada Bank Sentral dan Bank Koresponden.

\section{Prinsip-prinsip Pengelolaan Likuiditas}

Pengelolaan likuiditas harus dilakukan dengan cara hati-hati dengan memperhatikan prinsip- prinsip yang ada. Oleh karena itu dalam pengelolaan likuiditas bank, perlu diperhatikan beberapa prinsip pengelolaan likuiditas, yaitu :

1. Bank harus memiliki sumber dana inti (core source of fund) yang sesuai dengan sifat bank yang bersangkutan maupun pasar uang maupun sumber dana yang ada di masyarakat, serta yang cocok pula dengan mekanisme pengumpulan dana yang berlaku ditempat bank tersebut berada. 
2. Bank harus mengelola sumber-sumber dana maupun penempatannya dengan tepat sesuai dengan kriteria dana yang dihimpun. Oleh karena itu, harus diperhatikan komposisi sumber dana jatuh tempo berdasarkan jumlah masing-masing komposisi, tingkat suku bunga, faktor- faktor kesulitan dalam pengumpulan dana, produk-produk dana yang dimiliki dan sebagainya.

3. Bank harus memperhatikan different price for different customer didalam penempatan dananya, dan price (tigkat suku bunga) tersebut harus diatas tingkat suku bunga dana yang dipakainya atau dengan kata lain tingkat suku bunga atas penempatan dana tersebut harus bersifat floating.

4. Bank harus menaruh perhatian terhadap sumber dananya kapan akan jatuh tempo, jangan sampai terjadi maturity gap dan penempatannya (placement). Oleh karena itu, perlu diperhatikan prinsip pemenuhan kebutuhan dana yang sering menjadi acuan, yaitu :

1) Kebutuhan dana jangka pendek harus dipenuhi dengan sumber dana jangka pendek.

2) Kebutuhan dana jangka panjang harus dipenuhi oleh sumber-sumber dana jangka panjang.

5. Bank harus waspada bahwa tingkat suku bunga tersebut selalu berfluktuasi, naik turun dengan gerak yang susah ditebak sebelumnya (volatile). Oleh karena itu, agar bank tidak kehilangan sumber dananya, karena nasabah pindah ke bank lain, maka bank harus memiliki pricing policy yang baik, disamping itu harus mempunyai strategi ynag minimal mencakup strategi di produk, kekuatan dan hubungan.

6. Sesuai ketentuan perbankan, ekspansi aktiva suatu bank dipengaruhi oleh faktor- faktor berikut :

1) Aktiva Tertimbang Menurut Resiko (Risk Weighted Assets).

2) Capital Adequanty Ratio (CAR).

3) Net Open Position (NOP)

4) Loan to Deposit Ratio (LDR).

5) Batas Maksimun Pemberian Kredit (BMPK) atau legal lending limit.

6) Persentase Kredit Usaha Kecil (KUK) harus lebih besar dari $20 \%$.

\section{Tujuan dan Manfaat Pengelolaan Likuiditas.}

Tujuan dan manfaat dari pengelolaan likuiditas suatu bank secara umum adalah :

1. Untuk mengukur kemampuan bank dalam memenuhi semua kewajiban atau hutang yang segera jatuh tempo pada saat ditagih, artinya kemampuan untuk membayar kewajiban yang sudah waktunya dibayar sesuai jadwal batas waktu yang telah disepakati.

2. Untuk mengukur kemampuan bank membayar kewajiban jangka pendek dengan aktiva lancar secara keseluruhan, artinya jumlah kewajiban lancar dibandingkan dengan total aktiva lancar.

3. Untuk mengukur seberapa besar uang kas yang tersedia untuk membayar hutang.

4. Sebagai alat perencanaan kedepan, terutama yang berkaitan dengan perencanaan kas dan hutang.

5. Untuk melihat kondisi dan posisi likuiditas bank dari waktu ke waktu dengan membandingkannnya untuk beberapa periode.

6. Untuk melihat kelemahan yang dimiliki perusahaan, dari masing-massing komponen yang ada di aktiva lancar dan hutang lancar.

7. Menjadi alat pemicu bagi pihak manajemen untuk memperbaiki kinerjanya, dengan melihat rasio likuiditas yang ada pada saat ini.

8. Untuk mengetahui apakah bank memiliki masalah dalam penghimpunan dan 
dan penyaluran dananya.

\section{Tingkat Kesulitan dalam Pengelolaan Likuiditas}

Menurut Slamet Riyadi (2006:49) Kesulitan yang timbul dalam pengelolaan likuiditas dapat dikelompokan menjadi 2 jenis, yaitu:

1. Kesulitan Likuiditas Temporer

Kusulitan likuditas temporer dimana bank tersebut masih memiliki likuiditas yang cukup untuk memenuhi kebutuhan operasional hariannya, tetapi jatuh temponya tidak match dengan kebutuhan pada saat itu. Kesulitan tersebut belum berakibat fatal, kesulitan likuditas tersebut bisa diakibatkan karena Penerimaan, sebagai akibat dari telah terjadi cut off time pada Bank Sentral, sehingga untuk kebutuhan kas atau giro pada Bank Indonesia saat itu saldonya menjadi tidak cukup atau negatif. Padahal keesokan harinya dana- dana tersebut telah bisa diterima secara efektif oleh bank yang bersangkutan.

2. Kesulitan Likuiditas Struktural

Kesulitan tersebut timbulnya karena adanya missmatch yang lebih lama dibandingkan dengan kesulitan likuiditas temporer, umumnya disebabkan karena pemberian kredit yang jangka waktunya tidak sesuai dengan jangka waktu tersediannya sumber dana.

\section{Metode dan Pendekatan dalam Pengelolaan Likuiditas Bank}

Pendekatan yang ditempuh oleh manajemen bank dalam menetapkan policy

likuiditasnnya secara umum dapat dibagi menjadi lima pendekatan, yaitu :

1. Self Liquiditing Approach

Yaitu pendekatan peningkatan likuiditas bank melalui peningkatan pembayaran kembali kredit dan penanaman dalam surat berharga, sesuai dengan tanggal jatuh temponya, dengan demikian, aktiva-aktiva tersebut dapat digunakan sebagai alat likuid, khususnya untuk membiayai permintaan kredit baru atau diinvestasikan lagi dalam bentuk surat-surat berharga.

2. Assets Sale Ability Shift Ability

Yaitu meningkatkan likuiditas dengan cara melakukan likuidasi atau penjualan terhadap aset-aset lainnya yang tidak produktif.

3. New Fund

Yaitu meningkatkan likuiditas dengan cara menciptakan sumber-sumber dana baru, bai dari masyarakat maupun dari dunia perbankan, misalnya menciptakan Traveller Check, Credit Card, deposito berjangka dan lain-lain.

4. Borrower Warning Flow

Yaitu meningkatkan likuiditas dengan melalui usaha yang lebih giat dalam menjaga kelancaran penerimaan angsuran dan bunga dari kredit yang diberikan.

5. Reserve Discount Window to Central Bank as Lender of Last ResorT

Yaitu meningkatkan likuiditas dengan jalan mengadakan pinjaman ke Bank Sentral sebagai pemberi pinjaman terakhir.

\section{METODE PENELITIAN}

Dalam pengumpulan data dan bahan untuk penelitian ini digunakan metode penelitian sebagai berikut :

\section{Metode Pengumpulan Data}

1) Studi Lapangan (Field Research)

Peninjauan langsung ke objek penelitian dipilih untuk meneliti hasil data primer. Penelitian langsung ke lapangan ini akan dapat membantu penulis untuk melengkapi data yang diperlukan. Adapun cara riset lapangan ini adalah dengan mewawancarai pihak-pihak yang berkepentingan, dalam hal ini adalah perusahaan atau instansi yang terkait.

2) Studi ke Pustaka (Library Research)

Penelitian yang dilakukan ke pustaka. Beberapa buku-buku ilmiah dan tulisan- 
tulisan yang berhubungan dengan pembahasan yang dilakukan.

\section{Metode Analisis Data}

Dalam menganalisa data, menggunakan analisa data kualitatif dan kuantitatif. Dimana metode kualitatif menggambarkan, memahami dan menjelaskan data yang diteliti selama penelitian berlangsung, sedangkan metode kuantitatif menganalisa perhitungan tingkat likuiditas pada Bank Tabungan Negara (BTN) Cabang Padang. Metode analisis ditinjau dari dua praktek yang perlu diterapkan, sehingga dapat diketahui sejauh mana pelaksanaannya. Apakah perbedaan yang timbul menyangkut prinsip dasar konsep itu sendiri, pertanyaan itu akan terjawab selanjutnya dari hasil analisa itu digunakan sebagai dasar pengambilan kesimpulan dan saran.

\section{HASIL DAN PEMBAHASAN}

\section{Analisis}

a. Quick Ratio (QR)

Quick Ratio Merupakan rasio yang digunakan untuk mengukur kemampuan bank dalam memenuhi kewajibannya terhadap para deposan (pemilik simpanan giro, tabungan dan deposito) dengan harta yang paling likuid yang dimiliki oleh bank.

Tabel 1

Perkembangan Quick Ratio Periode Desember 2013-Desember2015 (Dalam Jutaan Rupiah)

\begin{tabular}{|c|c|c|c|}
\hline Tahun & Cash Asset & Total Deposit & Quick Ratio \\
\hline $\mathbf{2 0 1 3}$ & 3.310. & 11.885. & $27,85 \%$ \\
& 554 & 754 & \\
\hline $\mathbf{2 0 1 4}$ & 3.382. & 13.231. & $25,56 \%$ \\
& 278 & 972 & \\
\hline $\mathbf{2 0 1 5}$ & 4.091. & 14.053. & $29,11 \%$ \\
& 972 & 926 & \\
\hline
\end{tabular}

Sumber: PT.BPD Sumbar,data diolah.

b. Banking Ratio

Banking Ratio Merupakan rasio yang digunakan untuk mengukur tingkat likuiditas bank dengan membandingkan jumlah kredit yang disalurkan dengan jumlah deposit yang dimiliki.

Tabel 2

Perkembangan Banking Ratio Periode Desember 2013 - Desember2015 (Dalam Jutaan Rupiah)

\begin{tabular}{|c|c|c|c|}
\hline Tahun & $\begin{array}{c}\text { Total } \\
\text { Loan }\end{array}$ & $\begin{array}{c}\text { Total } \\
\text { Deposit }\end{array}$ & BR \\
\hline Des & 11.155. & 11.885. & 93,85 \\
$\mathbf{2 0 1 3}$ & 045 & 754 & $\%$ \\
\hline Des & 12.314. & 13.231. & 93,06 \\
$\mathbf{2 0 1 4}$ & 785 & 972 & $\%$ \\
\hline Des & 13.277. & 14.017. & 94,71 \\
$\mathbf{2 0 1 5}$ & 042 & 926 & $\%$ \\
\hline
\end{tabular}

Sumber : PT.BPD Sumbar, data diolah.

c. Loan to Deposit Ratio

Loan to Deposit Ratio adalah rasio yang digunakan untuk mengukur komposisi jumlah kredit yang diberikan dibandingkan dengan jumlah dana masyarakat dan modal sendiri yang digunakan. 
Perkembangan Loan to Deposit Ratio PT. BPD Sumbar Periode Desember 2013 - Desember 2015

(Dalam Jutaan Rupiah)

\begin{tabular}{|l|l|c|c|}
\hline Tahun & $\begin{array}{l}\text { Total } \\
\text { Loan }\end{array}$ & $\begin{array}{l}\text { Total Deposit }+ \\
\text { Equity }\end{array}$ & LDR \\
\hline 2013 & 11.15 & 13.413. & $83,16 \%$ \\
& 5.045 & 953 & \\
\hline 2014 & 12.31 & 15.031. & $81,92 \%$ \\
& 4.785 & 126 & \\
\hline 2015 & 13.27 & 16.157. & $82,17 \%$ \\
& 7.042 & 527 & \\
\hline
\end{tabular}

Sumber : PT.BPD Sumbar, data diolah.

\section{PEMBAHASAN}

Perkembangan Quick Ratio pada BPD Sumbar Cabang Utama dalam 3 (tiga) tahun ini menunjukan kecenderungan yang berfluktuatif. Pada Desember 2013, Quick Ratio menunjukan angka sebesar $27,85 \%$, dan mengalami penurunan pada Desember 2014 sehingga Quick Ratio menjadi 25,56\%. Sedangkan pada Desember 2015 mengalami peningkatan menjadi 29,11\%.

Dari uraian diatas, dapat dilihat bahwa nilai Quick Ratio pada BPD Sumbar Cabang Utama dari Desember 2013 sampai Desember 2015 tergolong sehat, karena nilainya berkhisar dari $25,56 \%$ sampai $29,11 \%$, yang berarti Quick Ratio BPD Sumbar Cabang Utama dalam beberapa periode tersebut berada diatas nilai standar yang ditetapkan oleh Bank Indonesia yaitu berkhisar antara 15\% - 20\%. QR tersebut dapat dikatakan sehat karena penghimpunan dana pihak ketiga diimbangi dengan aset kas pada bank. Aset kas pada bank yang cukup dapat membuat bank mampu memenuhi kewajiban jangka pendeknya, sehingga bank terhindar dari resiko likuiditas dan hubungan yang baik antara bank dengan nasabah bisa terjaga. Perkembangan Banking Ratio pada BPD Sumbar Cabang Utama dalam 3 (tiga) tahun menujukan kecenderungan yang berfluktuatif. Pada Desember 2013, nilai Banking Ratio menunjukan angka sebesar 93,85\% mengalami penurunan pada Desember 2014 menjadi 93,06\% dan mengalami peningkatan pada Desember 2015 menjadi 94,71\%. Dari uraian diatas, dapat dilihat bahwa nilai Banking Ratio pada BPD Sumbar Cabang Utama dari Desember 2013 sampai Desember 2015 secara keseluruhan tergolong tidak sehat karena nilainya berkhisar antara 93,06\% sampai 94,71\%, hal ini menandakan bahwa nilai Banking Ratio pada BPD Sumbar Cabang Utama dalam beberapa periode diatas kurang sesuai dengan nilai standar yang ditetapkan oleh Bank Indonesia yaitu berkhisar antara $75 \%-85 \%$. Hal ini terlihat bahwa dari total deposit yang dihimpun disalurkan secara keseluruhan dalam bentuk kredit. Semakin tinggi nilai Banking Ratio maka tingkat likuiditas bank semakin rendah, karena jumlah deposit yang diterima digunakan untuk penyaluran kredit semakin besar, demikian sebaliknya. Nilai Banking Ratio yang lebih besar dari standar Bank Indonesia menunjukan bahwa bank tersebut membutuhkan dana yang lebih besar untuk membiayai kredit yang diberikan, sehingga tingkat likuiditas bank tersebut tergolong rendah.

Perkembangan Loan to Deposit Ratio pada BPD Sumbar Cabang Utama dalam 3 (tiga) tahun ini menunjukan kecenderungan yang berfluktuatif. Pada Desember 2013 nilai Loan to Deposit Ratio menunjukkan angka 83,16\%. Pada Desember 2014 menurun menjadi 81,92\%. Sedangkan pada Desember 2015 mengalami kenaikan menjadi 82,17\%.

Dari uraian diatas, dapat dilihat nilai rata-rata Loan to Deposit Ratio PT. 
BPD Sumbar Cabang Utama dari Desember 2013 sampai Desember 2015 berkhisar antara 81,92\% -83,16\%, ini menandakan bahwa nilai Loan to Deposit Ratio tergolong sehat karena sesuai dengan standar yang di tetapkan oleh BI yaitu $\leq 94,75 \%$ tergolong sehat.

\section{SIMPULAN}

Berdasarkan uraian penjelasan tentang analisis tingkat likuiditas pada hasil dan pembahasan yang dikemukakan pada bab sebelumnya, maka dapat disimpulkan analisis laporan keuangan pada PT. BPD Sumbar Cabang Utama dilihat dari rasio likuiditas adalah sebagai berikut :

1. Secara umum keadaan keuangan PT. BPD Sumbar Cabang Utama pada periode Desember 2013 - Desember 2015 berdasarkan pengukuran rasio likuiditasnya dalam keadaan likuid.

2. Keadaan keuangan pada PT. BPD Sumbar Cabang Utama jika berdasarkan hasil pengukuran Quick Ratio dalam keadaan sehat. Hal ini terlihat pada nilai Quick Ratio pada periode Desember 2013 - Desember 2015 berkisar antara 25,56\% - 29,11\%, nilai ini tergolong sehat walaupun berada diatas nilai yang ditetapkan oleh standar Bank Indonesia yang berkhisar antara 15\%-20\%.

3. Keadaan keuangan pada PT. BPD Sumbar Cabang Utama jika berdasarkan hasil pengukuran Banking Ratio dalam keadaan tidak sehat. Dilihat dari hasil penilaian Banking Ratio pada periode Desember 2013 - Desember 2015 berkisar antara 93,06\% - 93,85\%, nilai ini tergolong tidak sehat karena tidak berada diatas nilai standar yang tetapkan oleh Bank Indonesia yaitu 75\%-85\%. Semakin tinggi nilai Banking Ratio maka tingkat likuiditas bank semakin rendah.

4. Keadaan keuangan pada PT. BPD Sumbar Cabang Utama jika berdasarkan hasil pengukuran Loan to Deposit Ratio dalam keadaan sehat. Hal ini terlihat dari hasil pengukuran Loan to Deposit Ratio pada periode Desember 2013

\section{DAFTAR PUSTAKA}

Arifin, I. Z., \& Marlius, D. (2017). Analisis Kinerja Keuangan PT. Pegadaian Cabang Ulak Karang. https://doi.org/10.31227/osf.io/n2peu

Arizel, 2016. Analisis Laporan Keuangan Berdasarkan Tingkat Likuiditas Pada PT. Bank Tabungan Negara (BTN) Kantor Cabang Padang. Akbp Stie "kbp" Padang.

Dendawijaya, Lukman. 2001. Manajemen Perbankan. Jakarta : Ghalia Indonesia.

Handayani, M., \& Marlius, D. (2017). Analisis Tingkat Kesehatan PT. BPR Batang Kapas. https://doi.org/10.31227/osf.io/bq48z

Harahap, (2009), Analisis Laporan Keuangan,Edisi ke-1,PT.Raja Grafindo Jakarta.

Iswari, M., \& Fernos, J. (2019). Analisis Tingkat Kesehatan Bank Pada PT. Bank Pembangunan Daerah Sumatera Barat. https://doi.org/10.31227/osf.io/ja7ty

Jumingan, 2006. Analisis Laporan Keuangan. PT. Bumi Aksara, Jakarta.

Kasmir, 2008. Analisis Laporan Keuangan. PT. Rajagrafindo Persada, Jakarta.

Munawir, 2004. Analisis Laporan Keuangan. Liberty, Yogyakarta. 
Putri, Y. A., \& Marlius, D. (2018). Analisis Tingkat Kesehatan Bank Pada PT. Bank Perkreditan Rakyat (BPR) Jorong Kampuang Tangah Pariaman Cabang Padang. https://doi.org/10.31227/osf.io/r98pv

Rahmayeli, D. S., \& Marlius, D. (2017). Analisis Kinerja Keuangan Pada PT. Bank Perkreditan Rakyat (BPR) Batang Kapas Pesisir Selatan. https://doi.org/10.31227/osf.io/sz5db

Riyadi Selamet, 2006. Banking Assets And Liability Management, edisi ketiga, Fakultas Ekonomi Universitas Indonesi, Jakarta

RI UU No. 10 Tahun 1998, Tentang Perubahan UU No. 7 Tahun1992 tentang Perbankan.

Shanjaya, A. R., \& Marlius, D. (2017). Peranan Laporan Keuangan Dalam Kebijaksanaan Pemberian Kredit Kepada Calon Nasabah Pada PT. BPR Batang Kapas. https://doi.org/10.31227/osf.io/uxmg6

Susilo Sri, dkk, 1999. Bank \& Lembaga Keuangan Lain. Salemba Empat, Yogyakarta.

Suyatno Thomas, dkk, 1996. Kelembagaan Perbankan. PT. Gramedia Pustaka, Jakarta.

Syafri Harahap, Sofyan,2008. Analisa Kritis atas Laporan Keuangan. PT Raja Grafindo Persada, Jakarta.

Pudjo Muljono, Teguh, 1995. Analisis Laporan Keuangan Untuk Perbankan. Djambatan, Jakarta. 